

\title{
THE DIRECT ESTIMATION OF MĀORI VITAL RATES FOR RUAPUKE ISLAND, 1844-1845 AND 1850-1885
}

\author{
SIMON CHAPPLE \\ University of Otago
}

\begin{abstract}
Māori vital rates were not officially collected in New Zealand until 1913 (Pool 1977).There are few direct estimates of such rates — birth rates, death rates, infant mortality rates - before that date. The two available estimates show birth and death rates both at 32 per 1000 for the South Island for 1868-1874, and birth and death rates of 35 and 31 per 1000 respectively for Mangonui in 1878-1879 (Pool 1977: 111-13). Furthermore, the record holds no direct 19th century estimation of Maori infant mortality, little information on cause of death for Maori and no consideration of birth and death rates over a lengthy period of time.

This article takes advantage of an unusual collection of data on Māori births and deaths from the island of Ruapuke from 1844, when its collector the Reverend Johann Friedrich Heinrich Wohlers arrived on the island, to 1885 , when he died. Wohlers' (n.d. [a], n.d. [b]) registers allow direct calculation of birth and death rates, infant mortality rates and of age at death, and permit a breakdown of vital rates by sex. In addition they also allow some consideration of cause of death. This exercise in historical demography adds significantly to the small body of knowledge on Māori vital rates in the 19th century and thus has implications for understanding Maori population dynamics during that period.
\end{abstract}

\section{RUAPUKE: DEMOGRAPHIC HISTORY CIRCA 1820-1844}

Ruapuke is a small island of about 16 square kilometres in size, situated in the eastern reaches of Foveaux Strait, which separates the south of the South Island of New Zealand from Stewart Island. An archaeological survey indicates prehistoric Māori occupation (Coutts and Jurisich 1972). Near contemporary evidence indicates that it was settled in numbers by Ngāi Tahu arriving from the north sometime in 1818 or 1819 (Boultbee in Starke 1986: 107). The Ruapuke populations seem to have grown rapidly from settlement, due to its contemporary advantages in addressing possible Māori military threats from the north, in offering a strategic position in relation to 
the mutton birding islands further south, and in allowing ready access to trading opportunities offered by the presence of European sealers and whalers in Foveaux Strait. In 1827 John Boultbee reported one settlement, with 60 huts and "a good many natives" on the island (Boultbee in Starke 1986: 60-61). While Boultbee did not note any further settlements, in 1823 Captain Edwardson had earlier recorded six houses in a small settlement in Henrietta Bay (Anderson 1986: 45). The Ruapuke village was the largest settlement Boultbee reported in Foveaux Strait. Allowing between four to eight people over 60-66 huts gives a total Ruapuke Island population in 1827 of 240-530 people. Equally, if the 180 men observed by Boultbee (Starke 1986: 99) at a tangi were predominantly from Ruapuke, using a figure of 3.4 people per man taken from the first Ruapuke census in 1844 as a multiplier, an island population figure of 500-600 in 1827 is possible.

There is also evidence of a severe epidemic before 1844: "The measles are said to have killed large numbers of people at one time" (Wohlers n.d. [b]: Report 3). This is almost certainly the measles epidemic of 1835 which was widespread across southern Ngāi Tahu territory (Anderson 1998: 193, Evison 1993: 85-86). By the time of the first precise population estimates in 1844, the island had 197 Maori living on it. The population was distributed across seven or possibly eight small villages: Waiotakariri, Tauatemaku, Ruapuke, Awatuiau, Toti, Taeroahue, Kirikiri and Te Onepanau (Coutts and Jurisich 1972: 6). This measles epidemic may have been a prime cause of the population decline on Ruapuke from 240-600 people in the late 1820 s to about 200 people in 1844 .

In the 19th century, Ruapuke was a predominantly Māori community. In 1844 Bishop Selwyn reported only two Europeans living there (Selwyn's Journal, Appendix J in Howard 1940: 381). As such, it was unlike many of the other Foveaux Strait settlements which had mixed populations of male European sealers and whalers, partnered with Māori women (Anderson 1991, 1998).

\section{DATA}

Data on births and deaths on Ruapuke was collected by Wohlers between 1844 and 1885 during his time on the island as a missionary with the North German Missionary Society. While the Ruapuke population was small, starting at 197 in 1844 and falling to just 14 in 1881, Wohler's intimate knowledge of a small population, developed over a long period of time, would have contributed to the accuracy of the undertaking. Undercounting - always a problem in direct estimation - is consequently not likely to be a significant issue.

Almost all the original individual records from the 1844 to 1849 period were unfortunately lost in a fire in 1850 . However, aggregate birth and death data for 1844 and 1845, as reported by Wohlers to the North German 
Missionary Society, have survived and the reports have been transcribed and translated into English (Natusch 1969, Wohlers n.d. [b]). Individual name, age and sex data also survives on six deaths from 1845, and sex (male), approximate age (youths) and cause of death (drowning) are known for a further three of the 1845 deaths from Wohlers' reports and another account. These deaths appear to be the drowning of three young Ruapuke men, who were working for surveyor Edward Jollie, near the Clutha River. Jollie mentions one of these young men was about 19 years old (Jollie n.d.). The cause and approximate age at death of a further drowning (the chief Tuhawaiki in 1844) is also well-known (Hall-Jones 1943).

In this study, the 1850 to 1861 birth data was based on baptisms of those born during those dates. Where both baptism and birth records can be compared, there was very little baptism outside the year following birth for years. Even then, such baptisms could readily be captured as births in the year that birth occurred, since Wohlers included age or date of birth with each of his baptisms. From 1862 births were taken directly from the Ruapuke register of inhabitants.

Deaths from 1850 to 1885 were taken from the death register. There was one death added from birth records, a case of neonatal mortality.

Only those whose abode was listed as Ruapuke and who were recorded as wholly or partly Māori were included in the births and deaths.

Many of the dead had an exact age listed. However, older people were often described as being "about" an age. These people were coded as being exactly that age. Others had an age range attributed to them. These people were coded at the mid-point of the range. Finally, others were described as "old" or "very old" at death. These people were all coded as being on average 70 years of age at death, the oldest directly attributed age at death $(\mathrm{N}=20$, women, men=10). Coding these people as dying at five years younger or older respectively had an effect on average age at death of $+/-0.8$ years. The three "youths" who Wohlers reports drowned are, following Jollie above, coded as 19 years old.

Wohlers noted the mobility of the Ruapuke population, probably related to seasonal hunting and gathering and socialising patterns: "They don't reside here all the time, but a large number of them go now and then to Stewarts Island and other shores of this region" (Wohlers n.d.[b]: Report 3). In addition, he drew some cautions about the accuracy of his first attempts to collect births and deaths in 1844: "Probably some children are counted amongst the births who are more than one year old and probably several deaths have been forgotten" (Wohlers MS. n.d. [b]: Report 3).

Total base island population data for 1844 and 1846 was taken from Wohlers' reports in the Alexander Turnbull Library (Wohlers n.d. [b]) and for $1852,1861,1864,1868,1874,1878,1881$ and 1891 from official documents 
(Maori Censuses 1874, 1878, 1881, 1891; Mackay 1873). Population was log-linearly interpolated for the intervening years.

Given that Wohlers was the official registrar, it is almost certain he was also the primary source of this official population information, again giving the data a greater degree of consistency.

Interestingly, the census data in this largely Māori settlement do not show any evidence of an excess of adult men, with adult women being absent via marriage to Europeans, a demographic pattern that Anderson $(1991,1998)$ notes as typifying southern South Island Māori communities in the second half of the 19th century. Indeed, the number of adult males on Ruapuke is typically fewer than adult females: 58:67 in 1844, 38:40 in 1852, 30:36 in $1861 ; 14: 17$ in 1874, 6:9 in 1878 and 5:5 in 1881. This excess of adult Māori females in the area had also been recognised earlier by John Boultbee, who noted that "this may be owing to the wars which thin the number of men" (Boultbee in Strake 1986: 102). Boating accidents or a greater tendency for males to be geographically mobile are possible alternative explanations for missing adult males. In addition, Anderson's suggestion that Wohlers recorded "a decline in the female population on Ruapuke from 200 to 130 in only seven years" from 1846 to 1852 because of a loss of Māori women to European partners seems to confuse the female population decline with that of Ruapuke as a whole (Anderson 1998: 194).

\section{RESULTS}

There were 111 births and 139 deaths in total on Ruapuke over the period 1844-1845 and 1850-1885. The crude birth rate over the entire 1844-1845 and 1850-1885 period was 37 per thousand. The crude death rate was 47 per thousand.

In the two years between 1844 and 1845 there were 17 births and 33 deaths, a net loss of 16 people. In the 35 years between 1850 and 1885 there were 94 births and 106 deaths, a net loss of 12 people. The birth and death rates for 1844-1845 were 44 and 85 per thousand, giving an average annual rate of natural increase of -4.1 percent. For 1850-1885 birth and death rates were 36 and 41 per thousand respectively, giving an average annual rate of natural increase of -0.5 percent. Hence, over the period of the registers, much of the natural decrease was concentrated in the short 1844-45 period, and was mainly because of an elevated death rate.

The distribution of age at deaths, by sex, and as a total is shown in Table 1. The average age at death of the population, where there was an age estimate available, was 29.0 years $(\mathrm{N}=116)$. The average female age at death was 24.8 years $(\mathrm{N}=59)$, much lower than that of males at 33.8 years $(\mathrm{N}=56)$. There was one death almost immediately after birth with no sex recorded. Using a 
Mann Whitney test for non-normally distributed samples, the nine year age difference at death by sex was statistically significant at a 5 percent level $(\mathrm{U}=2.01)$. Considering age at death for those over age 20, the difference between male and female average ages was much smaller at 3.3 years, being 51.1 years for men and 47.8 years for women. This difference was not statistically significant.

Table 1. Ruapuke Māori deaths by sex and by age: $1844-45$ and 1850-1885.

\begin{tabular}{|lccc|}
\hline Age & Female deaths & Male deaths & Total Deaths \\
\hline One year or less & 12 & 5 & 18 \\
$1-4$ & 6 & 4 & 10 \\
$5-9$ & 7 & 4 & 11 \\
$10-14$ & 5 & 4 & 9 \\
$15-19$ & 2 & 7 & 9 \\
$20-29$ & 9 & 8 & 17 \\
$30-39$ & 3 & 4 & 7 \\
$40-49$ & 4 & 2 & 6 \\
$50-59$ & 1 & 2 & 3 \\
$60+$ & 10 & 16 & 26 \\
\hline TOTAL & 59 & 56 & 116 \\
\hline
\end{tabular}

There were 94 births for which infant mortality could be examined; 44 of these births were male, 49 were female and one had no sex attributed. There were 18 infant deaths: 12 female, five male and one of undetermined sex. Infant mortality as a whole was 191 per thousand. The female infant mortality rate was 245 per thousand, over double that of males at 114 per thousand. Not only that, female infants who died had shorter infancies. The average female infant who died lived for 120 days, while the average male infant who died lived for 220 days. The data indicate that neo-natal mortality (one month or less) was five infants (four females, one sex undetermined), while post-neonatal mortality (more than one month to a year) was 13 infants (eight females, five males). 
Table 2. Cause of death 1845 and 1850-1885.

\begin{tabular}{|lcc|}
\hline Cause of death & Number of deaths & $\%$ share of all deaths \\
\hline Old age & 19 & $17.3 \%$ \\
"Illness" or variant & 19 & $17.3 \%$ \\
"Consumption" or variant & 17 & $15.5 \%$ \\
Other, unique cause & 13 & $11.8 \%$ \\
Drowning & 10 & $9.1 \%$ \\
"Decline" or variant & 8 & $7.3 \%$ \\
Influenza & 6 & $5.5 \%$ \\
Whooping cough & 3 & $2.7 \%$ \\
Measles & 2 & $1.8 \%$ \\
Bronchitis & 2 & $1.8 \%$ \\
Dropsy & 2 & $1.8 \%$ \\
Fever & 2 & $1.8 \%$ \\
Inflammation of the chest & 2 & $1.8 \%$ \\
Inflammatory fever & 2 & $1.8 \%$ \\
Weakness & 2 & $1.8 \%$ \\
\hline TOTAL & 109 & $100 \%$ \\
\hline
\end{tabular}

Cause of death information is available for 109 people. Table 2 provides the information on main causes of death. Often the information provided on the cause of death is very vague, with cause described as "old age", "illness" or "decline" or similar. All drowning was male, comprising an extraordinary 17.9 percent of male deaths. Most drowning was a consequence of boating accidents. There are no female deaths from childbirth. Nor are there any reports of deaths due to infanticide. Only one violent death was recorded-a suicide of a woman as an apparent consequence of the accidental death of a child in her care. 


\section{DISCUSSION}

The analysis of the Ruapuke data adds considerably to very limited information on directly estimated Māori vital rates in the second half of the 19th century. However, all discussion below must be caveated by the small numbers and nationally non-representative nature of the data.

The overall birth rate of 37 per thousand is higher than that for the South Island of 32 and Mangonui (in the North Island) of 35 per thousand measured during the same period. Death rates in Ruapuke are also considerably higher than for those two areas: 47 per thousand, compared to 32 and 31 respectively. The figures for the other two areas are more likely to be affected by underenumeration than is the Ruapuke data.

The Ruapuke data also show much higher mortality in the 1840s than thereafter, suggesting significant health improvements from the $1840 \mathrm{~s}$ compared to the $1850-1885$ period.

At 194 per thousand, infant mortality on Ruapuke between 1850 and 1885 is much less than the 500 per thousand suggested by Hamlin (1842) as characteristic of the Māori population in the late 1830s and early 1840s, again suggesting a considerable improvement in life chances for Māori in the second half of the 19th century.

The lower average female age of death found in Ruapuke, driven by higher female mortality during childhood and especially infancy, is consistent with (i) considerably higher ratios of male to female children than predicted by normal birth ratios observed in Māori regional and national censuses of the 19th century (Chapple 2000, 2005) and (ii) lower estimated chances of survival of Māori girls in later 19th century Māori life tables (Pool and Cheung 2003, Statistics New Zealand 2006). The fact that girls were more likely to die than boys, who are well known to be biologically weaker, strongly implicates Māori social processes as the cause of excessive girl deaths (Anderson 1998; Chapple 2000, 2005; Houghton 1996; Thomson 1859; and see McKee 1984 for a wider discussion of social biases against female children leading to their excessive mortality). However, the extent to which the higher death rates of Māori female infants are a consequence of conscious, sex-selective infanticide cannot be resolved by the data.

The cause of death data, limited though it is, is a unique data set for 19th century Māori. It reinforces the importance of tuberculosis - consumptionfor 19th century Māori mortality. Additionally, almost certainly much of the "illness" and "decline" is unattributed tuberculosis. Somewhat more surprisingly, it suggests the largely unacknowledged importance of drowning for analysis of Māori male mortality—a classic mortality accident hump for young men. Māori were largely a coastal people and long distance travel by 
water was a feature of life, as was food gathering in seas, rivers and lakes. Hence exposure to risks of drowning was high. The nature of the sexual division of labour regarding food gathering, and the greater geographical mobility of prime age males, meant that they were more exposed to boating risks. A caveat here is that the elevated rate of drowning on Ruapuke may be due to the unusually risky waters of Foveaux Strait. However, it should be noted that four of the ten drownings occurred further up the east coast of the South Island, not in the Strait, and another involved a young boy drowning in a well. Hence drowning is a plausible candidate for some of the overall excess of adult females over males observed in the Ruapuke data. Additionally, drowning of adult Māori males may have been an important but previously unacknowledged push factor for southern Ngāi Tahu women in the region to seek European husbands.

The data suggest a population with a reasonably strong birth rate but a high basal death rate across most of the life cycle owing to endemic tuberculosis, combined with time-variant bursts of viral and bacterial epidemic disease - such as measles, influenza and whooping cough — predominantly killing children.

This pattern is likely to be different from that of the period before the 1840 s, when there was neither much less acquired or genetically selected disease immunity at any age, nor much community experience of dealing with the challenges posed by mass all-ages sickness. Hence, earlier, these modern childhood diseases would have killed more widely across the age span and at higher rates.

Given 40 years of virtually continuous contact with European shipping largely out of eastern Australia, a local collection hub for both European and Asian origin diseases, by 1844 these microbes and viruses were no longer highly destructive "virgin soil" epidemics. Acquired immunity, genetic selection and social adaptations could cushion their impact.

A further difference is likely to have been in the possibly declining virulence of tuberculosis. Socio-economic disruption and warfare was more common in the region before 1844 and this is a factor known to exacerbate death rates from tuberculosis (Dubos and Dubos 1987). Additionally, in the earlier half of the 19th century violence probably directly accounted for a significant proportion of deaths. A considerable number of violent deaths are mentioned by Boultbee during his short sojourn in the region during the mid-1820s, for example.

The Ruapuke data suggest the importance of drowning as a cause of death and that those drowned were typically prime aged males, and likely to be temporally bunched, owing to the loss of crewed boats or canoes.

Lastly, it is worth mentioning that the Reverend Wohlers made some strong published claims regarding the relationship of births to deaths on Ruapuke. 
These include: "I found when I kept an exact register of births and deaths that there was only one birth to three or four deaths" (Wohlers 1895: 125) and "when I arrived amongst the Maoris in 1844 I found the death rate so high that there was only one birth to three or four death" (Wohlers 1895: 204). While Wohlers' data do show population decline, the ratios of births to deaths approach a maximum of one birth to two deaths in the 1844-1845 period and generally average much less than this. Wohlers' stylised pronouncements do not match his own data: the Ruapuke population was more robust than he portrays.

\section{ACKNOWLEDGEMENTS}

Thanks to Paul Callister for his input. The usual disclaimer applies.

\section{REFERENCES}

Anderson, Atholl, 1986. Te Puoho's Last Raid. Dunedin: Otago Heritage Books. 1991. Race Against Time. The Early Maori-Pakeha Families and the Development of the Mixed-race Population in Southern New Zealand. Dunedin: Hocken Library, University of Otago.

- 1998. The Welcome of Strangers: An Ethnohistory of Southern Maori AD 16501850. Dunedin: University of Otago Press.

Chapple, Simon, 2000. Why there were more Maori men than women and what changed it. New Zealand Population Review 26 (1): 45-66.

2005. Sex inequality in the Maori population in the prehistoric, proto-historic, and early historic eras in a trans-Polynesian context, Journal of Pacific History 40 (1): $1-21$.

Coutts, Peter and Mark Jurisich, 1972. Results of an Archaeological Survey of Ruapuke Island. Otago University Monographs in Prehistoric Anthropology, vol. 5. Dunedin.

Dubos, Rene and Jean Dubos, 1987. The White Plague: Tuberculosis, Man and Society. 2nd ed. New Brunswick (NJ): Rutgers University Press.

Evison, Harry, 1993. Te Wai Pounamu—The Greenstone Island: A History of Southern Maori during the European Colonisation of New Zealand. Wellington: Aoraki Press.

Hall-Jones, F.G., 1943. King of the Bluff. Invercargill: Southland Historical Committee. Hamlin, James, 1842. On the Mythology of the New Zealanders. London, J. Murray. Houghton, Phillip, 1996. People of the Great Ocean. Cambridge: Cambridge University Press.

Howard, Basil, 1940. Rakiura. Dunedin: Reed.

Jollie, Edward, n.d. MSS. Reminiscences, 1841-65. Alexander Turnbull Library, Wellington.

Mackay, Alexander, 1873. A Compendium of Official Documents Relative to Native Affairs in the South Island. 2 volumes. Wellington: Government Printer. 
Maori Census 1874. Appendices to the Journal of the House of Representatives, Session I, G-07, Wellington: Government Printer.

1878. Appendices to the Journal of the House of Representatives, Session I, G-02, Wellington: Government Printer.

-1881. Appendices to the Journal of the House of Representatives, Session I, G-03, Wellington: Government Printer.

-1891. Appendices to the Journal of the House of Representatives, Session II, G-02, Wellington: Government Printer.

McKee, Lauris, 1984. Sex differentials in survivorship and the customary treatment of infants and children. Medical Anthropology 8 (2): 91-108.

Natusch, Sheila, 1969. Brother Wohlers. Christchurch: Pegasus Press.

Pool, Ian, 1977. The Maori Population of New Zealand, 1769-1971. Auckland: Auckland University Press.

Pool, Ian and Jit Cheung, 2003. A cohort history of mortality in New Zealand. New Zealand Population Review 20 (2): 107-38.

Starke, June (ed.), 1986. The Journal of a Rambler. The Journal of John Boultbee. Auckland: Oxford University Press.

Statistics New Zealand, 2006. A History of Survival in New Zealand: Cohort Life Tables 1876-2004. Wellington: Statistics New Zealand.

Thomson, A.S., 1859. The Story of New Zealand. 2 volumes. London: John Murray. Wohlers, Johann Friedrich Heinrich, 1895. Memories of the Life of J.F.H. Wohlers. Dunedin: Otago Daily Times and Witness Company.

-n.d.(a) Ruapuke Registers. Alexander Turnbull Library, Wellington.

n.d.(b) Ruapuke Reports, MS-Papers-0428-04A. Alexander Turnbull Library, Wellington.

\begin{abstract}
Vital rates and cause of death for Māori on the island of Ruapuke are examined for the period 1844 to 1885 . Natural decline is evident over the period, but is lower for later years. Infant mortality is higher for females. Cause of death data suggests the importance of both tuberculosis and periodic childhood epidemics for general mortality, as well as drowning for adult males.
\end{abstract}

Keywords: Māori, Ruapuke, 19th century, vital rates, mortality

\title{
CITATION AND AUTHOR CONTACT DETAILS
}

Chapple, ${ }^{1}$ Simon, 2014. The Direct Estimation of Māori Vital Rates for Ruapuke Island, 1844-1845 and 1850-1885. Journal of the Polynesian Society 123 (4): 421-430. DOI: 10.15286/jps.123.4.421-430

${ }^{1}$ Corresponding author: Department of Preventive and Social Medicine, University of Otago, PO Box 56 Dunedin, 9054. E-mail: simon.chapple@otago.ac.nz 